\title{
How Dutch employees experience freedom of learning for work
}

\author{
Theo van Dellen ${ }^{1} \cdot$ Ina Heidekamp ${ }^{1}$
}

(C) The Author(s) 2015. This article is published with open access at Springerlink.com

\begin{abstract}
This article focuses on the perceived freedom of Dutch employees to embark on workplace learning in terms of whether they feel it is "voluntary" or "compulsory". The paper is based on the findings of a large international explorative survey carried out by the Workplace Learning (WPL) Research Network (RN2) of the Asia-Europe Meeting (ASEM) Lifelong Learning (LLL) Research Hub. The comparative study focused on employees' quest for "freedom of learning for work". This paper reports on the Dutch part of the research, the quantitative results of which seem to indicate that the freedom of learning for work is not as important to Dutch employees as might be expected. In a second phase, to investigate employees' experiences of work-related learning in more depth, the Dutch researchers added a follow-up qualitative study, involving one-on-one interviews. In order to triangulate the results of the quantitative and qualitative research phases, the authors then added a mixed-methods sequential explanatory analysis. They assessed the quality of the collected data in both distinct phases by identifying converging results, which are useful for refining our understanding of learning for work. The paper draws both on rich insights into workplace learning based on this research as well as on theoretical literature which refers to concepts like motivation, subjectivity, work identity and agency in connection with the quest for freedom of learning.
\end{abstract}

Keywords Work-related learning - Motivation and emotion · Workplace learning · Mixed-methods sequential explanatory design $\cdot$ Freedom of learning

Theo van Dellen

t.van.dellen@rug.nl

Ina Heidekamp

h.g.heidekamp@alumnus.rug.nl

1 Educational Sciences, University of Groningen, Groningen, The Netherlands 
Résumé Comment les employés néerlandais vivent-ils la liberté d'apprendre pour leur travail ? - Cet article aborde la question de savoir si les employés néerlandais perçoivent la possibilité d'apprendre sur leur lieu de travail comme une liberté ou une contrainte. L'article est fondé sur les résultats d'une vaste enquête exploratoire internationale, menée par le réseau de recherche 2 sur l'apprentissage en milieu professionnel (Workplace Learning Research Network, RN2) du pôle de recherche en apprentissage tout au long de la vie du Dialogue Asie-Europe (ASEM LLL Hub). L'étude comparée explore chez les employés le désir d'être « libres d'apprendre pour son travail ». L'article présente la contribution néerlandaise à cette étude, dont les résultats quantitatifs semblent indiquer que cette liberté importe moins aux employés néerlandais qu'il pouvait être escompté. Lors d'une seconde phase consistant à approfondir l'expérience des employés avec l'apprentissage lié au travail, les chercheurs néerlandais ont ajouté une étude qualitative de suivi impliquant des entrevues individuelles. Afin de trianguler les résultats des phases quantitative et qualitative, les auteurs ont alors ajouté une analyse explicative séquentielle au moyen d'une méthodologie mixte. Ils ont vérifié la qualité des données collectées lors des deux phases en dégageant les résultats convergents, qui s'avèrent précieux pour affiner notre appréhension de l'apprentissage en situation professionnelle. Ils se sont appuyés pour la rédaction de cet article à la fois sur les riches enseignements de cette étude relatifs à l'apprentissage professionnel, et sur la documentation théorique concernant des concepts tels que motivation, subjectivité, identité professionnelle et agentivité en rapport avec le désir d'être libre d'apprendre.

\section{Introduction}

For some years now, Asian and European researchers of the Workplace Learning (WPL) Network of the Asia-Europe Meeting (ASEM) Lifelong Learning (LLL) Research Hub ${ }^{1}$ have studied to which extent workplace learning opportunities are more fruitful when motivation is positive and learning participation is voluntary and not compulsory (Chisholm, Lunardon, Ostendorf and Pasqualoni 2012). The starting question of the Network was: what do employees experience to be "voluntary" and "compulsory" with respect to workplace learning? Moreover: how might this dialectic aspect of employees' perception of work-related learning be connected with their motivation to learn and their experiences with the learning they have been offered or have undertaken (Chisholm, Van Dellen and Lunardon 2012a, b)?

This issue of experiences with learning for work, including workplace learning (WPL) and work-related learning (WRL), ${ }^{2}$ is of particular interest in the

\footnotetext{
${ }^{1}$ According to its own website, "The ASEM LLL Hub, established in 2005, is an official network of Asian and European higher education institutions, working and learning together to achieve excellence in comparative research on lifelong learning, to offer research-based education policy recommendation, and to develop mutual understanding between Asia and Europe." See http://asemlllhub.org/aboutus/ organogram/ [accessed 9 November 2015]. The Workplace Learning (WPL) Network is one of five networks within the hub.

${ }^{2}$ While workplace learning (WPL) is on-the-job learning, work-related learning (WRL) is off-the-job learning.
} 
Netherlands, because compared to other European countries (OECD 2012), Dutch employees invest less of their working life - in total 0.6 years - in formal and nonformal training and development (WRR 2013). In addition, Dutch investment in formal education which leads to qualification is also relatively lower (OECD 2012). These figures recently led two ministers in the Dutch government (Bussemaker and Asscher 2014) to call for a stronger learning climate, in particular in middle and higher vocational educational institutions. However, according to the same government, this will not be enough. A real learning climate is characterised by employers and employees who are motivated and flexible to learn and to invest accordingly in themselves to keep their knowledge and skills on track (ibid.).

Irrespective of this governmental call, Dutch employees' participation in formal learning has over the past 10 years been quite constant and in fact relatively high at 50-60 per cent in a two-year window (Borghans et al. 2014). Moreover, in the same period of ten years (2004-2013), employees indicated that the share of working time necessary enable informal learning lies between 30 and 35 per cent (ibid.).

In terms of reasons why workers follow a work-related course, the figures collected in a survey by Lex Borghans et al. (2014) show a kind of dichotomy between reasons typically of interest to employers and reasons of more interest to employees. For instance, a major interest of the employers may be a compulsory work course (mentioned by $39 \%$ of the respondents), new tasks (30\%) and new ways of working (23\%). By contrast, reasons which seem to be more in the interest of the employees include realising career goals $(36 \%)$, inadequate knowledge or experience $(33 \%)$ and higher job perspectives (22\%). Finally, when learning for work concerns informal learning, this seems to occur in particular in collaboration with experienced colleagues, when activities become challenging and whenever activities are "new" (Borghans et al. 2014).

In the Netherlands, learning for work in its (non)formal as well as informal form is a somewhat problematic issue in practical terms. Although there is a belief that learning in the workplace should emerge from the work situation itself, the emphasis, like in other European countries, is still on organised learning. Moreover, concrete benefits of working and learning, such as salary, promotion and recognition, appear to be more important to most employees than the learning experience itself, despite the insight that intrinsic motivation to learn outweighs extrinsic motivation. In addition, most work(place)-related learning is still very individual and cognition-oriented, while the issue of power and control is always present. Nevertheless, Dutch employees, even the younger ones, seem to have high expectations and are critical towards their employer in matters concerning learning for work. Finally, it seems clear that "workplace" is not synonymous with "learning environment" and that organisational environments with their (lifelong) learning policies and practices operate in specific sectorial, socio-cultural and macroeconomic contexts.

These considerations brought us to the quest for "freedom of learning for work" - the focus of our study. In our research, we explored experiences of Dutch employees in order to better understand their perception of the concepts of "compulsion" and "volition". In other words, we were interested in how Dutch employees' freedom of learning is situated in the concrete everyday world between 
socio-economic working and learning structures and personal subjectivities of motivation, identity and agency. Although in this paper we do not go further into the above in terms of learning climate policy and concept, our research results do at least indirectly indicate some experiences of employees with the learning environments they are confronted with.

Our research consists of three phases. The first phase is quantitative, with a mixed-methods sequential explanatory design in which the voluntary-compulsory dimension of freedom of learning is explored through motivational aspects of employees' learning experiences. Next, in the follow-up qualitative second phase of our study, we clarify the freedom of learning concept in philosophical terms by relating learning for work to interviewees' life circumstances. Finally, the two phases are combined in the third phase, in which the mixed-methods approach is completed by comparing and interpreting the outcomes of both phases from the perspective of the quest for "freedom of learning for work".

\section{Conceptual framework}

The slogan "lifelong learning is learning from the cradle to the grave" is on the one hand preached to, or even imposed on, the public by governing authorities, employers, unions and sector organisations, to clarify that people need to continue learning throughout their lives, because their employability is their own responsibility (Van Dellen 2012). On the other hand, lifelong learning theory and practice emphasise the autonomy of adults in being able to freely choose their own learning goals and to voluntarily participate in suitable lifelong learning (LLL) programmes. Although this may be the case for a small proportion of adults, for the majority of the population learning seems to be a more or less compulsory affair, one which obliges people above all things to adapt to the ever-changing work environment (Illeris 2007; Jarvis 2007; Van Dellen 2012). Yet, while compulsory or voluntary learning is not good or bad in itself, it can be considered to be a phenomenon of ambiguous and multi-dimensional adult learning processes and practices. While the concepts of compulsion and volition have never been operationalised, the dialectical characteristics of the two concepts do hypothetically relate to motivation and emotion. That is, the dialectic could arouse employees' interest, inspiring and encouraging them to pursue knowledge, upskilling and personal development.

Within our conceptual framework (Figure 1), (lifelong) learning is related to human living itself; learning is understood as an existential and experiential endeavour (Sloterdijk 2011; Verplaetse 2008, 2012; Jarvis 2006). The individual is located as a learning subject in a conditioned, stimulating and supportive sociocultural and working environment, with each component intertwining with and mutually affecting the others (see also e.g. Illeris 2007; Jarvis 2007). Accordingly, reciprocity is considered significant and interdependence a "fact of life". Even so, German philosopher and cultural theorist Peter Sloterdijk premises an inherent selfmotivating drive, directing and energising the human being to practise self-training and self-discipline, which can gradually lead to "infinitely improbable" performances. Yet, individual efforts in self-improvement and changing one's life are 


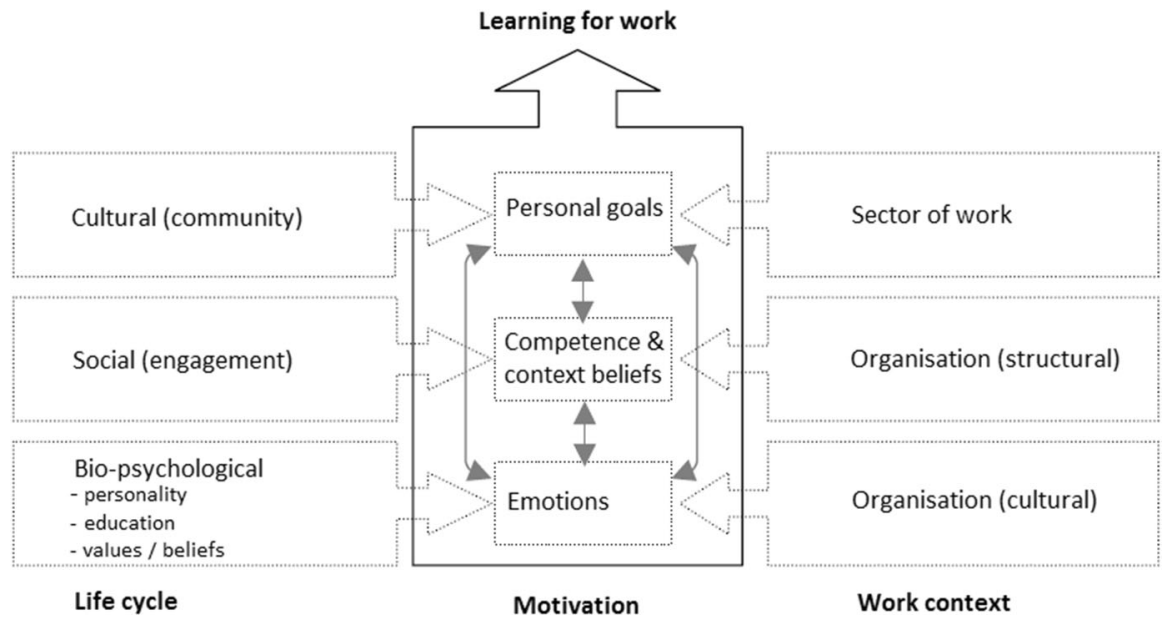

Fig. 1 The "Learning for work" conceptual framework based on Ford and contextualised through the work of Verplaetse

restricted by causal bio-psychological and socio-cultural determinants. Nevertheless, "self-mastery" potentially "empowers", increases individual control and opportunities, and expands the practice zone for individuals and society as a whole. Peter Sloterdijk and Jan Verplaetse argue that the effect of external influences is ultimately determined by the individual's (physical) ability to adapt and the willingness to do so, because emotions, morals, ethics, ideologies, beliefs and (economic) values all affect our (non)conscious decisions. Because of this view of human nature and culture, Verplaetse pleads for understanding and mildness towards human shortcomings and failure, while Sloterdijk rather strictly calls for an attitude and practice of self-discipline. However, as an internal and external causal determination of human behaviour is assumed, both philosophers declare "free will" to be illusionary, while accrediting the individual with an "own will", which still gives every one of us some control over changing ourselves, our own life and the world we live in, for the better.

These philosophical ideas bring us to the topic of our research on "learning for work" and the freedom (if any) of learning Dutch employees experience in this respect in the context of everyday life. Motivation and emotion seem to be crucial for developmental activities of adults, their participation in (non)formal training programmes and their work(place)-related learning behaviour. Martin Ford, who developed his Motivational Systems Theory (MST) by combining and integrating different views of humans and empirical scientific findings in a coherent theoretical framework, defines motivation as:

the organized patterning of three psychological functions that serve to direct, energize, and regulate goal-directed activity: personal goals, emotional arousal processes and personal agency beliefs (Ford 1992, p. 3). 
He is convincing in showing that motivation is a cyclic internal evaluative process which values "goals" through emotions (and vice versa) by considering beliefs about the situated competence and context (see Figure 1). In the case of work, for instance, the contextual requirements to learn might follow David Ashton (2004): opportunity to practise; motivation and prior experience; satisfaction with work; support for learning; and reward for learning. So, according to Ford's theory, motivation is an internal process, belonging to the individual, where personal goals are seen as feelings and thoughts about the (un)desired outcomes which individuals seek. Personal goals playing an "emotional" role in motivation are always owned accepted and personalised - by the individual. Thus, motivation should be understood as in essence a psychological, future-oriented and evaluative phenomenon (Van Dellen 2012).

Our further exploration of lifelong learning "theories" and their different perspectives on working and learning - i.e. gerontological, historical, sociological, psychological and organisational - resulted in a tentative definition of "freedom of learning in the context of labour" as: the personal decision space to make one's own choice in work-related learning.

Next, we developed a three-dimensional conceptual model of the personal decision space, adopted from the philosophical perspectives mentioned above and drawn from the background of motivational theory. Primarily though, we were inspired by Verplaetse's Without a Free Will (Verplaetse 2012), the Four Drive Theory of Human Nature by Paul Lawrence and Nitin Nohria (to acquire, to bond, to learn and to defend; Lawrence and Nohria 2002), Ford's MST (Ford 1992) and the indirect notions of Elwood Holton and Sharon Naquin (2005) on decision-making in training and development. MST shows: what drives a person (elementary goal direction, based on intuition and emotions; i.e. "feeling"), why does he/she want it (motivated goal focus, based on conscious beliefs and values; i.e. "thinking") and how the individual puts it into practice (the efforts made and the support given; i.e. "doing"). The what, why, and how are integrated in the motivational centre of our conceptual model based on Ford's work. Our model is completed with a fourth dimension, the qualitative and quantitative time of life. An individual sets the actual score by his/her decision through every "own will" learning activity undertaken informally or (non)formally. Thus, (lifelong) learning takes an objective and a subjective position in life, in time and space: place, moment and duration of the learning activity, as well as the meaning and value it has emotionally, morally and economically in the life cycle and the work context.

We designed our conceptual framework (Rocco and Plakhotnik 2009) "learning for work" on three pillars (see Figure 1). The central pillar is based on Ford's idea of motivation as an evaluative process which organises the personal decision to learn for work. The pillar to the left concerns the personal life context and the pillar to the right concerns the organisational work context. Horizontally, each pillar consists of three levels: the top level is the bio-psychological, emotional and organisational cultural level (from left to right), the next level is the social, competence and context, organisational structural level and the bottom level is the societal, personal goals and sectoral organisational one. There is a fourth "ongoing" 
time dimension as well, namely the present-future learning for work for which choices have been made and learning for work was initiated.

In the first phase of our study, we explored motivational and affective aspects of learning around workplaces in a quantitative manner by way of a survey. We hypothesised that different sectors of the labour market influence employees' experiences differently. This idea was based on prior organisational research projects, which brought to light differences in terms of Human Resource Development (HRD) policies, activities and content in the sectors of healthcare and the metal industry, specifically in the configuration of professional development in the healthcare sector and organisational development in the metal industry (Bolt and Van Dellen 2006; Van Dellen and Hauwen 2007). In the second phase of our study, we went further into the conceptualised motivational and affective aspect through interviewing a sample of participants about their experience with work(place)-related learning activities. This qualitative aspect is of interest to employees and employers, as well as to lifelong learning practitioners and researchers, in order to learn more about freedom of learning from deliberations of people situated in restrictive or expansive learning work environments (Van Dellen and Greveling 2010). Finally, in the third phase we used both the quantitative and the qualitative sources to go further into the "freedom of learning for work"(life).

\section{Methodology}

\section{The mixed-methods research design}

A mixed-methods explanatory research design provides the opportunity to learn more and to gain a deeper understanding of a central phenomenon - in our case employees' experiences with freedom of learning for work - by taking advantage of the strength of having three research phases (Creswell 2007; Ivankova et al. 2006). The purpose of these different phases of our study was to be able to validate our results by "triangulation". Validation is increased by results which point in the same direction (convergence). Although triangulation was initially only conceptualised as a strategy for validating results obtained by way of individual methods, the focus has now shifted towards further enriching and completing knowledge (Flick 2007). According to Uwe Flick, triangulation is less a strategy for validating results and procedures, but more an alternative to validation, which "increases scope, depth, and consistency in methodological proceedings” (2007, p. 390, emphasis added). In triangulation, the results of quantitative and qualitative instruments are compared to find out whether they support or contradict each other and to interpret the outcomes accordingly (Creswell 2007). Figure 2 visualises the sequence of the distinct research phases, their procedures and products of our research explicitly.

\section{Samples}

In the first phase of the research, more or less arbitrary members of organisations/companies in (1) public services, (2) health and welfare, (3) metal and 


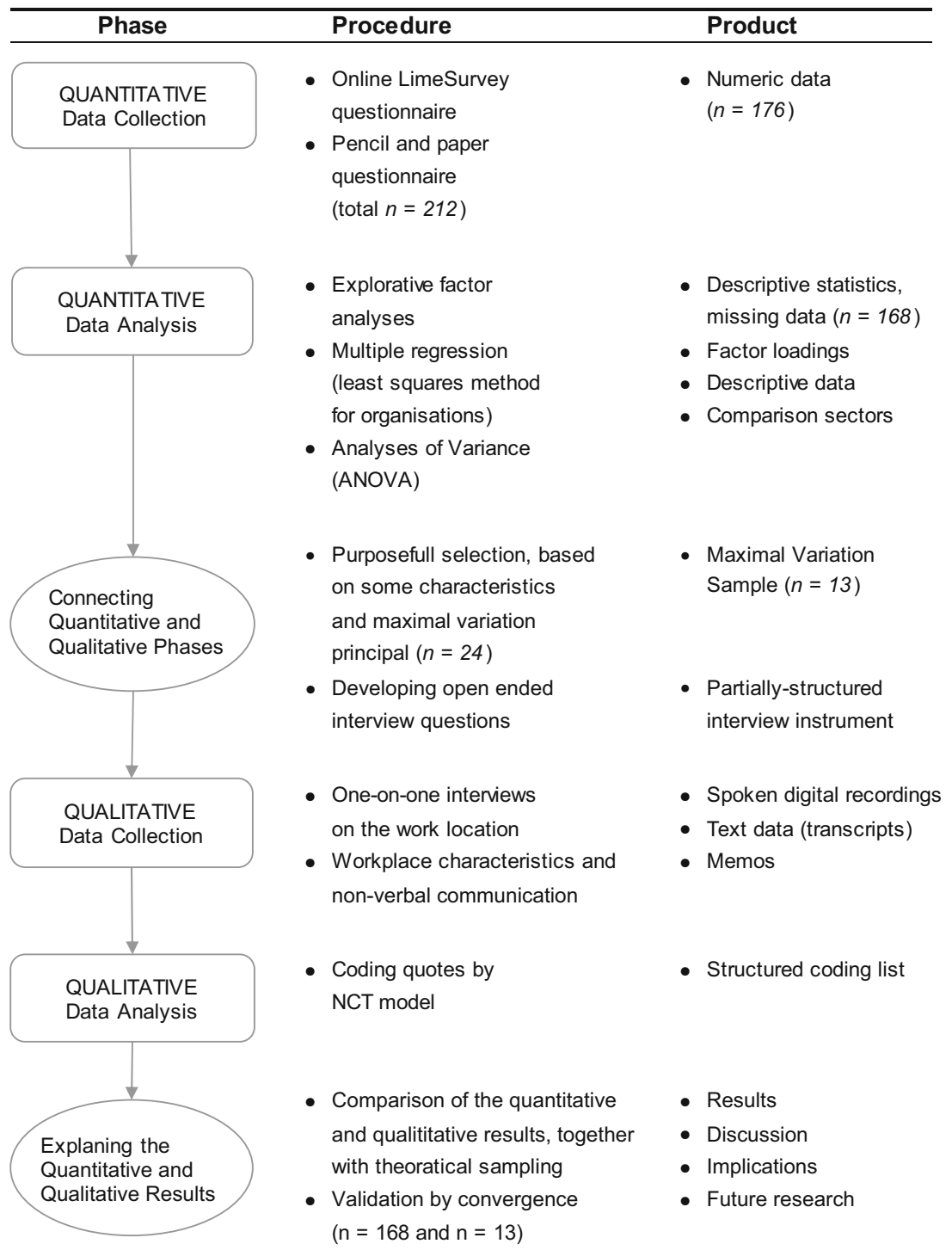

Fig. 2 Visual model of the mixed-methods sequential explanatory procedures, adapted from Ivankova et al. (2006, p. 16)

technical installation, and (4) commercial services, known to the researchers from prior projects, were asked (by e-mail or phone, or directly by visiting) to participate in the study and to encourage colleagues and executives to do the same. These organisations were not chosen for reasons which might have suggested they somehow struggled differently than other organisations with the issue of freedom of learning. The decision to choose these four sectors was, however, based on some evidence that differences between them had been hypothesised and on reasons of 
Table 1 Number of respondents and participants working in selected differentiated sectors

\begin{tabular}{|c|c|c|c|c|}
\hline \multirow[t]{2}{*}{ Sector } & \multicolumn{2}{|c|}{$\begin{array}{l}\text { First, quantitative phase } \\
\text { Respondents }(n=168)\end{array}$} & \multicolumn{2}{|c|}{$\begin{array}{l}\text { Second, qualitative phase } \\
\text { Participants }(n=13)\end{array}$} \\
\hline & Number (Org.) & Percentage & Number (Org.) & Percentage \\
\hline Public Services & $37(11)$ & 22.0 & $3(2)$ & 23.1 \\
\hline Health \& Welfare & $58(19)$ & 34.5 & $7(5)$ & 53.8 \\
\hline Metal \& Technical Installation & $28(11)$ & 16.7 & $3(2)$ & 23.1 \\
\hline Commercial Services & $34(14)$ & 20.2 & & \\
\hline Other & $11(9)$ & 6.5 & & \\
\hline Total & $168(64)$ & 100.0 & $13(9)$ & 100.0 \\
\hline
\end{tabular}

resemblance and comparability in the international part of the research. In this way, a sample of 212 people was obtained within a reasonable time frame. Although 176 employees responded (83\%), after counting out those with missing data, the final sample size was $168(79.2 \%)$. Table 1 presents the number of respondents and organisations for each sector in the first two phases of our research. The "other" sector category included participants from other sectors of work, like education.

In the first research phase, the ratio of men (47\%) and women (53\%) who participated was almost equal. The results show that $52.7 \%$ of them had completed higher vocational education or university and $47.3 \%$ had completed non-higher education, e.g. secondary education. In terms of age, the respondents were classified into four categories: $20-30$ years old $(n=48), 30-40(n=41), 40-50(n=40)$ and $50+(n=35)$. Finally, the tenure of the respondents in their current organisation was divided into three categories: $0-8(n=97), 8-15(n=37)$ and more than 15 years $(n=33)$.

In the second phase of our study, we complemented the quantitative nature of the first phase with a strategy of maximal variation sampling (MVS), ${ }^{3}$ to obtain qualitative information by way of one-on-one interviews. Out of the 168 respondents in the first phase, a purposeful sampling of 24 individuals was drawn from only three sectors: public services, health and welfare, and metal and technical installation. Of those people invited to participate in the research, 13 were willing to participate in the qualitative study. Two of them did not participate in the quantitative study. They were a pilot interviewee from the health and welfare sector and an employee in the metal industry whom we had added to get sufficient variation in this sector. Because data saturation was already reached, further selection was not necessary, and besides not desirable because the overall ability of the researcher to provide an in-depth picture diminishes with the addition of each new individual (Creswell 2007). The right-hand side of Table 1 presents the numbers of the interviewed participants and the organisations for each sector involved.

\footnotetext{
${ }^{3}$ The principle of maximum variation sampling (MVS) is to select a small number of cases which maximise the diversity relevant to the research question.
} 
Although balanced gender participation was attempted in the second phase, more women $(n=9)$ than men $(n=4)$ participated in the research. Their age was spread across a range of 24-66 years, and the range of tenure in the current organisation was 4-26 years. The respondents were all well-educated: non-higher $(n=1)$ and higher secondary education $(n=2)$, non-higher vocational education $(n=2)$, higher vocational education $(n=6)$, and university $(n=2)$.

\section{Instruments}

As described in our introductory section, we took part in an international network developing the questionnaire which assessed motivational and affective components around work and learning in organisations in Asia and Europe (Chisholm, Van Dellen and Lunardon 2012a, b; Van Dellen and Greveling 2010). Because there was a lack of available scales or questionnaires assessing these components in the way we were interested in, we reviewed relevant literature and discussed it in order to develop items around work and learning which considered the dialectic of compulsion and volition. Besides general descriptive sample indicators, our questionnaire contained items concerning experiences with organisational practices of work and learning, such as employer's attitudes towards workplace learning (WPL) and employee's motivation to work and to learn. Mostly the experiences of the respondents with these indicators were measured by their ranking items on a five-point Likert scale.

In the second phase, we investigated "why", "what", "how" and "when" of learning for work, i.e. the personal decision space. To refine and elaborate the explorative outcomes from the first, quantitative phase in this respect, we developed a partially-structured interview instrument with four open-ended questions and several sub-questions for further clarification or deeper understanding of the research topics. The EDucation Against Marginalisation (EDAM) ${ }^{4}$ Guideline for Partially-Structured Interviews was used to develop the interview protocol, the content of which was based on our quantitative results. The interview questions were inspired by the EDAM evaluation instrument from a learner perspective. They intended to bring to light individual experiences and moral-ethical considerations about working and learning (Holton and Naquin 2005).

\section{Procedure}

Participation in the first phase of the study was voluntary and all the participants were informed about the research goals. To ensure confidentiality, they were guaranteed that the data would be used for research purposes only. The quantitative data were collected by using an online LimeSurvey ${ }^{5}$ questionnaire over a period of three to four months, ending in 2010 (Van Dellen 2012; Van Dellen and Greveling

\footnotetext{
${ }^{4}$ EDucation Against Marginalisation (EDAM) was a multilateral European project which lasted from 2009 to 2011. It involved conducting a survey in its nine partner countries (The Netherlands, Belgium, Italy, Austria, Romania, Greece, Denmark, Germany and Switzerland). The purpose of the project was to enhance the effectiveness of adult education in terms of improving social inclusion of the participants.

5 LimeSurvey is an online survey application which is free and open source.
} 
2010). A paper version was made available for respondents who were not able or willing to use the online questionnaire. Respondents who did not reply were reminded to do so, up to three times.

The same research ethics we applied in the first phase were adhered to in the second phase: participation was voluntary, interviewees were informed about the research goals and confidentiality was assured. Due to the schedule of the participants and the working student-researcher, the qualitative data were collected from October 2012 to April 2013. Thirteen employees from nine different organisations were interviewed at their workplace. Thus, besides the digitally recorded and saved spoken research material, impressions of the work environment and -climate were obtained. Moreover, the possibility of gaining a better understanding of participants' learning behaviour in the daily, specific, complex social context on the job, increased by visiting the employees in their organisational "habitat" (Creswell 2007; Flick 2007; Friese 2012).

\section{Analysis}

We analysed our survey data by means of $\operatorname{SPSS}^{6}$ with explorative factor analyses (Varimax-rotation), multiple regression and analysis of variance. The survey items concerning the motivational and affective aspects of learning for work were subjected to a factor analysis, in order to explore the possible underlying constructs of work, in particular its possible compulsory and voluntary aspects (Van Dellen and Greveling 2010).

To analyse the qualitative research material in the second phase, we used Atlas $t i$ computer software. ${ }^{7}$ The interview transcriptions and memos were imported into a hermeneutic unit (Friese 2012). During a first coding cycle of the raw data, text segments ("quotes") were coded on the basis of the quantitative results, theoretical notions and by association with the empirical qualitative data, until saturation occurred. The codes were structured and categorised on a conceptual and content level, using Susanne Friese's model of Noticing things, Collecting things and Thinking about things (NCT; Friese 2012). Some of the codes were merged or split and renamed.

In order to find similarities and differences in the analysed datasets, we compared the results of both research phases with each other in relation to our conceptual framework (Figure 1). Through comparison, statistical outcomes can be supported by qualitative themes and vice versa (Creswell 2007). According to John Creswell, possible data triangulation or convergence in a single study is an attractive approach, albeit labour intensive and time consuming as well as difficult and controversial, because the quantitative scores and the qualitative text have to be compared in some way. One way is to compare the two sources of data, to determine whether the themes emerging from the face-to-face interviews support or refute

\footnotetext{
${ }^{6}$ SPSS, an acronym for Statistical Package for the Social Sciences, designates a software package initially created for the social sciences. It is now being used for statistical analyses by researchers of other fields of study.

7 Atlas ti is a computer programme which is especially suited for the analysis of qualitative data analysis.
} 


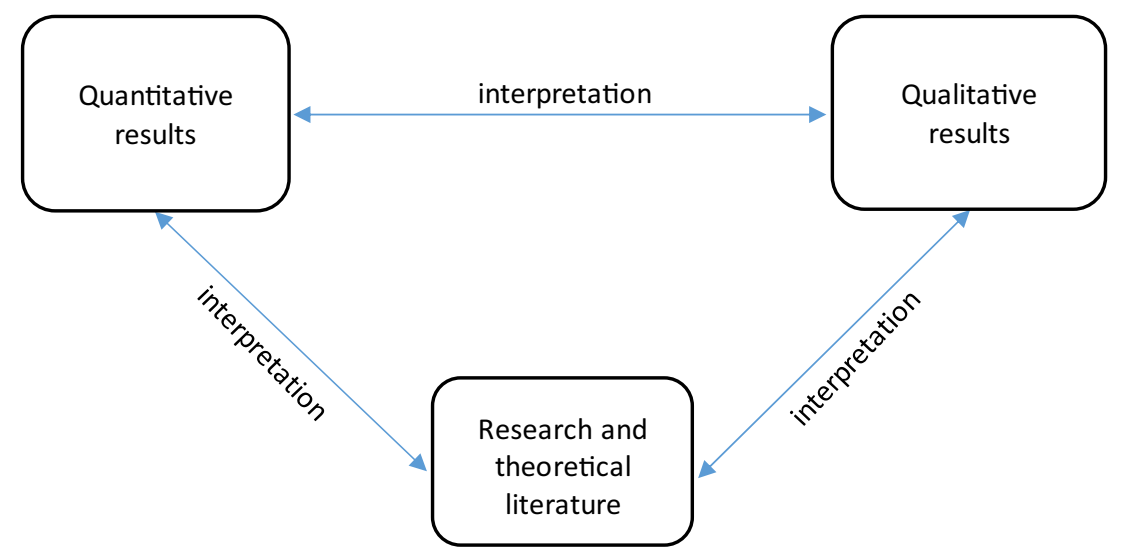

Fig. 3 Explanatory analysis of the compared results of study phases 1 (quantitative) and 2 (qualitative), research and theoretical literature

explorative conceptualisations and analysis. Another way is to quantify the qualitative themes and then to compare the frequency directly with the descriptive scale statistics. In this final phase of our study, we used both ways of mixedmethods comparative analysis: between groups (Dutch sample and MVS) and within the group of interviewees (see Figure 3). In addition, we compared our results with the issues around working and learning emerging from research and theoretical literature.

\section{Results}

In this article, we report only on the comparable results concerning the quest for freedom of learning for work of the first and second phase of the research. More extensive outcomes of the two research phases are separately reported elsewhere (Van Dellen 2012; Heidekamp 2014).

\section{Quantitative results}

Table 2 shows the six plausible and understandable scales with motivational and affective connotations and relative acceptable reliabilities. These scales were the outcome of an explorative factor analysis. The contents of the items within every scale are reported in Table 3 in the first column on the left. All items had high factor loadings ( $>.60)$.

The Dutch employees highly agreed with the statement that even in cases where they decided for themselves to pursue learning for work, their employer would expect relevancy as well as importance for the job (the mean job-related approval was 3.95 on a 5-point scale). The significant but small correlation of this scale with the construct of contextual expectations to take courses $(r=.23)$ indicates that jobrelated approval rises and falls somewhat with the social norms of colleagues and 
Table 2 Descriptive statistics and inter-correlations for the constructed variables

\begin{tabular}{|c|c|c|c|c|c|c|c|c|c|}
\hline Constructed scales & $\alpha$ & $\mathrm{N}$ & $\mathrm{M}$ & SD & 2 & 3 & 4 & 5 & 6 \\
\hline $\begin{array}{l}\text { 1. Workplace learning (WPL) activities } \\
\text { satisfaction }\end{array}$ & .77 & 153 & 3.07 & 0.78 & $.58^{* *}$ & $.17^{*}$ & & & $.22 * *$ \\
\hline 2. Learning opportunity & .76 & 163 & 2.90 & 0.89 & & $.23 *$ & $.27 * *$ & & $.44 * *$ \\
\hline 3. Work satisfaction & .67 & 165 & 4.00 & 0.82 & & & & & \\
\hline 4. Employer's necessary consent & .52 & 164 & 3.60 & 0.96 & & & & & \\
\hline 5. Employer's job-related approval & .70 & 160 & 3.95 & 1.02 & & & & & $.23 * *$ \\
\hline 6. Contextual expectations to take courses & .62 & 167 & 3.30 & 0.98 & & & & & \\
\hline
\end{tabular}

$* p<.05$ (two-tailed); $* * p<.01$ (two-tailed)

employers. The employers' job-related approval is indicative for the "compulsionvolition" debate. It seems that the more employees agree with "voluntariness is important for learning", the more strongly they experience the need for their employer's approval; which expresses the dialectic of freedom of learning.

Next, we found a very strong interdependence $(r=.58)$ between the constructs "WPL activities satisfaction" $(\mathrm{M}=3.07)$ and "Learning opportunity" $(\mathrm{M}=2.9)$. The first addresses motivational and affective learning components, the latter describes the experienced opportunities offered by the employer to participate in learning. In addition, both have clear relationships with: "Work satisfaction", and "Contextual expectations to take courses". This means that both are positively related to appreciation for and good feelings about the work one is doing. Besides, a "Learning opportunity" is more strongly recognised and experienced when colleagues and employers expect, or even insist, that employees should take courses $(r=.44)$. At the same time a "Learning opportunity" on its own correlates positively with "Employer's necessary consent" $(r=.27)$.

Next, two multiple regressions were executed (weighted by organisation), for a better understanding of the relationships between the motivational and affective constructs (and the descriptive sample variables [sector, tenure, gender, age, organisation size, education level; for an extensive description, see Van Dellen 2012]). In this regression we took "WPL activities satisfaction" as the dependent variable, because the experienced activities are in some respect the result of the motivational process and the decisions being made by the employees in the context of working and their life cycle. The analysis shows, first, that "WPL activities satisfaction" is lower in the commercial and public services sectors than in the other sectors; second, that a tenure of 8-15 years working for the same employer gives lower satisfaction with learning activities to the other tenure categories (see the "Samples" section above); and third, that higher experience of "learning opportunity" strongly increases satisfaction with learning. The other sample predictors did not show any influence (Van Dellen 2012). Finally, another motivational and affective construct differs between the sectors: the "Contextual expectation to take courses" is significantly lower in the metal and technical installation sector than in the other sectors (ANOVA, $\mathrm{F}=6.48, \mathrm{p}<.01$ ) 
Table 3 Converging results of the comparative analysis

\begin{tabular}{|c|c|c|}
\hline $\begin{array}{l}\text { Constructed scales and } \\
\text { corresponding items }\end{array}$ & Qualitative $(s u b)$ themes & $\begin{array}{l}\text { Research and theoretical } \\
\text { literature }\end{array}$ \\
\hline
\end{tabular}

[1] Workplace learning (WPL) activities satisfaction

In my organisation, workplace learning activities:

- are mostly enjoyed by participants

- receive strong support and engagement from other employees

- reflect the fact that individual exchange of knowledge is important for participants

- are emotionally important for all participants

[2] Learning opportunities

My employer:

- offers such attractive learning opportunities that most of us want to take them up

- offers a lot of learning opportunities compared with other similar employers in my kind of work

- tries to make sure that therés enough time and space to learn during working hours

- gives recognition to employees who improve their knowledge and skills (e.g. salary rise, promotion, appreciation)
Quality of WPL activities

\section{Satisfaction}

interest, fun, capacity, selfesteem

colleagues, good fellowship

social learning, informal learning: colleagues, customers/clients/patients

daily practice at work (relevancy), improving job performance, motivated by challenge and change, employer's initiative, little own efforts

Quality and quantity of

Workplace learning activities

inspiration, stimulation, challenge, change, added value to job performance

employer's expectations, employer's initiative, relevancy of WRL

support, little private time and financial investment

appreciation, recognition emotional arousal, personal agency beliefs, affection

congruence (Ford 1992; Illeris 2007), internal/external integration

drive to learn, drive to bond (Lawrence and Nohria 2002), interaction: $\mathrm{I} \leftrightarrow \mathrm{Me}, \mathrm{I} \leftrightarrow$ Thou* (Jarvis 2006)

practical integration in (work) biography (Jarvis 2007; Ashton 2004), disjuncture, interaction $\mathrm{I} \rightarrow$ Envisaged It** (Jarvis 2006), drive to acquire (Lawrence and Nohria 2002), acquisition (Illeris 2007), learning for earning (Jarvis 2007), secondary control, adjustment (Heckhausen et al. 2010)

emotional arousal, goal activation (Ford 1992), drive to learn (Lawrence and Nohria 2002), opportunity to practise (Ashton 2004)

distribution of knowledge and information (Ashton 2004)

support for learning (Ashton 2004)

goal direction, focus (Ford 1992; Lawrence and Nohria 2002), motivation and prior experience, reward for learning (Ashton 2004), drive to acquire (Lawrence and Nohria 2002), acquisition (Illeris 2007), learning for earning (Jarvis 2007) 
Table 3 continued

\begin{tabular}{|c|c|c|}
\hline $\begin{array}{l}\text { Constructed scales and } \\
\text { corresponding items }\end{array}$ & Qualitative $(s u b)$ themes & $\begin{array}{l}\text { Research and theoretical } \\
\text { literature }\end{array}$ \\
\hline
\end{tabular}

[3] Work satisfaction

How would you judge your current situation at work?

- The work I'm doing makes me feel good

- I feel appreciation for the work I'm doing

[4] Employer's necessary consent If you decide yourself to pursue WRL, how does your employer usually respond?

- My employer never agrees to my participation in WRL courses

- My employer only lets me participate when the course is required by the organisation

[5] Employer's job-related approval

If you decide yourself to pursue WRL, how does your employer usually respond?

- If it takes place during working hours, my employer wants to see its relevance for the job

- If it costs a lot, my employer expects me to show it is important for my job

[6] Contextual expectations to take courses

Please tell us whether you agree or disagree with the following statement:

- In my organisation everyone expects you to take courses from time to time
Quality of work

competences, independence, responsibility

informal learning, work performance

Sensitivity to authority

position, self-motivation, support, dependence, decision space

position, relevancy, autonomy, motivated by challenge and change

\section{Sensitivity to authority}

mutual consent on relevance, little private time and financial investment

self-motivation, at own costs, decision space

adjustment, survive in the external world (Lawrence and Nohria 2002), learn for life (Jarvis 2007), primary control (Heckhausen et al. 2010)

discretionary power (Illeris 2007)

congruence, material resources (Ford 1992)

congruence, material resources (Ford 1992)

beliefs, morals, ethics, values

(Holton and Naquin 2005)

\section{Learning climate}

stimulation, inspiration, decision space secondary control (Heckhausen et al. 2010), adjustment, survival (Lawrence and Nohria 2002)

emotional arousal (Ford 1992) 
Table 3 continued

\begin{tabular}{|c|c|c|}
\hline $\begin{array}{l}\text { Constructed scales and } \\
\text { corresponding items }\end{array}$ & Qualitative $(s u b)$ themes & $\begin{array}{l}\text { Research and theoretical } \\
\text { literature }\end{array}$ \\
\hline $\begin{array}{l}\text { Most employers insist that their } \\
\text { employees follow training } \\
\text { courses at regular intervals }\end{array}$ & dependence, decision space & $\begin{array}{l}\text { personal agency beliefs (Ford } \\
\text { 1992), morals, ethics (Holton } \\
\text { and Naquin 2005) }\end{array}$ \\
\hline
\end{tabular}

$* \mathrm{I} \leftrightarrow \mathrm{Me}$ (relationship with the self) and $\mathrm{I} \leftrightarrow$ Thou (relationship with other individuals) are part of Peter Jarvis's "The person-in-the-world" model, depicting a person's awareness of his/her life history and educational biography (Jarvis 2006, p. 15, Fig. 1.3)

** I $\rightarrow$ Envisaged It is also part of Jarvis's “The person-in-the-world” model (ibid.)

\section{Qualitative results}

The interviewees were asked to rate their work and their learning on a scale of 1-10 (from 1, not important at all, to 10, of utmost importance). The mean marks given for work and learning were 7.5 and 8.2, respectively.

Our transcriptions show that the interviewed employees considered having their priorities right, including the regrets of some who felt hindered in living up to their full learning potential. These priorities with respect to working and learning were of great concern and moreover shifted during and after major life events. The interviewees verbalised upfront what they most aspired to: "earning a livelihood for myself and my family", "meaningful connections, work and training that fits", "acknowledgement", "new challenges", and "professional and personal development". But keeping the "work-learn-life balance" seems to be burdensome, particularly during vocational education, because of the simultaneous efforts necessary in three domains of life: (family) care, work, and education —all taking a toll on the leisure domain. Still, within the second phase sample, we found a remarkable upward mobility, since the interviewees were above average in terms of the amount of vocational training they had engaged in as an adult: 6 out of 13, which is $46 \%$ compared to $12 \%$ national participation in programmes lasting longer than six months. Since only one interviewed employee was fully supported by the employer, it also became quite clear that the workers themselves were responsible for their vocational training. Among the main themes in this respect were: family support, individual living conditions, dedication, (mental) health, interest and employability.

In terms of non-vocational "on the job" and "off the job" training, several (sub)themes were identified: practical use (relevancy), compulsory learning, ownership, quality of peer relationships (colleagues), fit to individual learning needs and personal beliefs, learning opportunities and organisational position. The outcomes of work(place)-related learning show that (the frequency of) nonvocational training is selectively provided to the respondents, depending on their position in the organisation or company, so WPL seems poorly democratised. Still, all employers offered courses, e-learning programmes, coaching or mentorship to their employees. 
Unfortunately the interviewees did not always have an emotional or practical interest in work-related courses offered by the employer, but they played along if courses were, however directly, of use for improving their job performance; and if they were interesting or pleasurable, the interviewees reported to have been committed participants. But some of our respondents also morally/ethically rejected learning opportunities (e.g. "waste of money") and some saw to it themselves if the employer failed to serve their learning needs. Nevertheless, overall, the respondents demonstrated a high work-satisfaction and they appreciated the non-vocational learning opportunities their employers offered to them, although such offers were apparently limited to the basic principle of consensus about the relevancy of the training.

\section{Results compared}

The analysed converging results from both mixed-methods research phases are presented in Table 3, together with related (empirical) findings in relevant literature. Reflecting on the content of the text data, taking the quantified quotes into account, and evaluating the qualitative analysis process, some main and subthemes about (freedom of) WPL emerged. Although those themes differed in frequency and similarity of subthemes and categories, they were brought up by all the interviewees. The presented (sub)themes, emerging from single interviews and across interviews, related to the willingness and readiness of workers to participate in WPL activities. The recurring qualitative (sub)themes at the different constructed variables, as shown in Table 3, confirm the statistical correlations. In addition, some of the expected theoretical issues about adult (work-related) learning did emerge, which adds to the validation of our research results.

\section{Workplace learning activities satisfaction}

Satisfaction with work(place)-related learning activities was quite evident in both the quantitative and the qualitative part of the research. According to our interviewees, they enjoyed the activities because of the pleasurable interaction with their colleagues during the training, although they sometimes felt insecure about their own learning performance in the group. Indeed, the quantitative "satisfaction with learning" scale in particular includes some items with a social content (see Table 3). Moreover, several motivational and affective aspects of social learning and learning together are addressed in the literature, e.g.: emotional arousal, congruence, personal agency beliefs (Ford 1992), drive to bond (Lawrence and Nohria 2002) and interaction (Jarvis 2007). So the satisfaction may not be due to their experienced (lack of) affinity with the content of the learning activities, because the content was often not consistent with the personal and professional knowledge and experience. For this reason, and the fact whether or not the employer initiated and organised WPL activities, the extent of their dedication to learn differed accordingly among participants. This converges with the high score (3.95) on the employers' necessary consent in our quantitative investigation. The reasons why the informants nevertheless participated in WPL activities were phrases like 
"possibly something new can be learned anyway (you never know)" or "knowledge and skills can be refreshed" (see also Ashton's [2004] opportunity to practice, motivation and prior experience); participation is mandatory; WPL is during working hours and paid for by the employer; and finally: it is an opportunity for personal and professional development to improve one's job performance. So, doing their job well seems to have been important to all the participants.

\section{Learning opportunities}

The construct of learning opportunities indicates the amount and quality of the nonformal learning activities being offered to the examined Dutch workers by their employers. The mean learning opportunities scale score was relatively low at 2.9. This score covered the attractiveness and the number of opportunities offered as well as available time and recognition for the employees. Nevertheless, all the interviewees had been given the opportunity to participate in learning several times. Their employers offered a range of opportunities, such as (e-learning) courses, coaching or mentoring. However, for the reasons described above, employees participated more or less voluntarily, also because the employer's offer made them feel recognised and appreciated; constituting motivational and affective MST components (Ford 1992). Besides, more than once they had felt stimulated and inspired by the suggested learning activities, resulting in their decision to seize the opportunities to learn more, in order to improve their work performance and to increase their job satisfaction (emotional arousal and goal direction MST terms). Our respondents did not talk about (material) benefits of WPL, such as a salary raise or promotion. Hence, the activities/opportunities seem to contribute mainly to motivational and affective aspects. Moreover, some felt disadvantaged, because of unequal (quality) and fewer (quantity) opportunities they were offered, compared to people in higher positions. This converges well with the relatively low learning opportunities score. This outcome seems to be one of the reasons why employees rarely, if ever, take the initiative to ask for learning opportunities, or choose to create such opportunities themselves. Only in a few cases did employees decide to pursue non-formal WRL themselves, or occasionally to reject a learning opportunity. According to Knud Illeris, adults exercise their discretionary power because they want to learn purposefully what is meaningful to them. Still, the opportunities to learn "on the job" depend to a high extent on employers' willingness to offer WPL activities to their employees. This does not, however, hold for urgent and incidental learning. Colleagues learning from each other seems to be a common and valued practice at the workplace which is barely noticed and recognised by executives and employers. Besides learning from their peers, employees also learn for example from trainees and through reading professional journals.

\section{Work satisfaction}

Work satisfaction concerns emotional bonds with work. As expressed by the participants of our study, work gives them a sense of belonging and the feeling to be someone. The rating given by the interviewees in terms of how important they felt 
this aspect to be was somewhat lower (7.5) than in the quantitative phase, although these data are hard to compare in a straightforward way. This can probably be explained by the fact that the interviewer asked a slightly different question, namely to indicate how important work is in the wider context of their lives, including the material benefits of work. What is of great importance to the interviewed employees is that their work suits them. This matches with Lawrence and Nohria (2002), who identified internal integration as one of the functions of human drives and also with Jutta Heckhausen et al. (2010), who differentiated between employees taking primary control or secondary control of their (working) lives. So our respondents seemed to strive for a high standard of work performance, taking pleasure in using and increasing their competencies to do their work well. The interviewees expressed that they liked to carry out their work activities independently and that they felt responsible for the work they were doing. Autonomy is also an aspect in the work of Edward Deci and Richard Ryan $(1985,2000)$. This sense of autonomy at work, the idea of a factor like a "learning freedom belief", meaning the "freedom" to participate in decision-making and choosing the content of learning, positively influences their desire to learn (Van Dellen 2012). As described before, the interview results showed that several people pursued qualifying vocational education by themselves. It may be that the interviewees and the survey respondents who did this demonstrated a high "learning freedom belief" despite the importance of the employer's role in decisions. This issue is further addressed in the next paragraph and in the discussion.

\section{Employer's necessary consent}

"Employer's necessary consent" showed the conditions under which the employer lets the employee participate in learning when the employee has decided to do so (see Table 3 for the items in the left column). The threshold to this consent is rather high, meaning that employers do not easily give their consent. Our analysis further showed a positive relationship of consent with "learning opportunities", which can plausibly be explained by the information given by the interviewed employees. First, they feel taken seriously by their employer if the opportunity to learn is offered to them, an MST congruence aspect (Ford 1992). Second, the participant may hit upon new ideas and perspectives by the offer of the employer. In this respect, employees seem to experience being offered WPL activities as a favour. And because the employer is the offering party, consent is not an issue. But it is a high-risk issue if employees decide themselves to pursue WRL. At the same time, our interviewees agreed about the required consent, because WPL activities in general are paid for by the employer. Sometimes, however, if the desired training is important to the participants, they take care of it themselves, at their own cost. Illeris (2007) terms this "discretionary power". Nonetheless, this construct remains an indication of the employer's position of power as already noted elsewhere (Van Dellen 2012). It seems that while employees are expected to take care of their sustainable employability, if they do take the initiative, the climate of the organisation they belong to may not always turn out to be supportive. 


\section{Employer's job-related approval}

With the "employer's job-related approval" construct from the survey, the results of the interviews also show a considerably high level of convergence (Table 3). This means that employees agree with the employer's conditional approval and that they should prove that the WRL they are pursuing is indeed relevant and important for their job. According to the interviewees, this is reasonable because the employer pays for it and the learning activities mostly take place during working hours, so WPL activities are potentially accessible for everyone. But at the same time it is clear that participation in WPL is highly dependent on the social and material environment people work in (Illeris 2007).

\section{Contextual expectations to take courses}

The correlation of the former construct with "Contextual expectations to take courses" indicates that the employer's approval is also influenced by what might be called aspects of the contextual "learning climate" at the level of colleagues, employers in general, as well as the broader sector level in the community (see Figure 1). But "Contextual expectations to take courses" is also strongly related with "Learning opportunities". Thus, when everybody in the organisation, including employers, generally expects or even insists that employees should take courses and are learning while they are working, employees indicate they experience more opportunities, irrespective of whether these are explicitly offered or not. This converges with the information of the interviewees who felt stimulated and inspired by the offered learning possibilities, as discussed above.

\section{Conclusions}

Overall, the quantitative part of our research (phase 1) showed that freedom of learning or the personal decision space to make one's choice is somewhat ambiguously conceptualised, with a distinction being made between compulsion and volition of WPL, although all the defined constructs contained aspects of both (Van Dellen 2012). The freedom of learning seems to be rather restricted (Ellström 2011) on one side through employers' requirement of job-relatedness and their necessary consent, while being enabled on the other side by expectations and opportunities. Thus WPL activities are in themselves neither voluntary nor compulsory. To Dutch employees this does not seem to be an issue, because learning is a continuing secondary condition in the context of their employment, their work context and their lives. Moreover, the contract between employer and employee is still strongly powered by economic dependence in the first place and psychological relatedness in the second. This relatedness can be stimulating as well as frustrating at the same time and affect employees' employability-enhancing activities. We therefore recommend that further research on freedom of learning in WPL activities should focus on the issue of decision-making around WPL activities as such (see Figure 1). Prior to our own study, a start had already been made by 
Holton and Naquin (2005), who did go into this issue with respect to policy- and decision-making around human resource development in organisations.

Comparing the numeric data and qualitative transcriptions (phase 2), we identified some potential influencing factors on WPL. Our study resulted in a better understanding of the meaning of working and learning within organisational structures from the perspective of employees. But the discrepancy between the hypothesised influence of contextual power relations on WPL and the results of the quantitative study raised new questions about employees" "free" learning space in the context of labour.

These results seem to show that true voluntariness of participation in WPL possibly does not actually exist. The relation of learning opportunities and the idea that employees ought to be willing to learn shown by some of the employees who feel free to reject their employer's training offer if it seems at odds with their morals and ethics seem to indicate this. Moreover, in cases where their employer fails to serve their learning needs, most employees see to it themselves, to the best of their abilities. These findings, again, reflect the dialectical compulsion-volition dimension. The current renewed scientific interest in informal learning (as mentioned earlier in our introduction) seems justified, because our informants frequently emphasised that they highly valued (incidental) learning in daily (work)life from colleagues and family members (partner, children).

In conclusion, it seems that learning and working do matter to Dutch employees. Moreover, they apparently utilise their personal decision space by making their own best possible choices in work(place)-related learning, at specific moments in life. Disregarding individuals' striving for internal and external integration of whatever learning decision is unlikely to lead to the personal and professional growth desired by everyone concerned: the person and organisation involved, or society as a whole. Ultimately, the individual appears to be "the host", owner as well performer, of learning. Thus, lifelong learning policies and practices would be well advised not to reckon without this "host". Learning opportunities and programmes should therefore be created and developed with respect to the human scale, aiming for internal and external integration of the "lessons to be learned" by the individual.

Finally, two diverging results should be mentioned. Our quantitative research showed lower satisfaction with WPL activities in the public service sector, compared to the other sectors. But the information proffered by the interviewed employees in this sector does not confirm this outcome, and this lack of corroboration also applies to another difference between the sectors. The variable of "contextual expectations" to participate in courses, another motivational and affective construct, is significantly lower in the metal and technical installation sector than in the other sectors. The difference in results might be explained by the small sample of interviewees, in addition perhaps to too little variation. Another plausible explanation could be that the interviewees apparently worked in what you might call atypical organisations within these sectors.

Learning for work is a very complex consideration for employees, with pros and cons needing to be weighed up against each other. These pros and cons originate in the internal experience of working and goal-setting in connection with beliefs about one's own competence and the more or less supportive environment. This evaluative 
motivational process is fed by emotions and cognition concerning the work context and the life cycle (including personal, family, social and cultural aspects). Of course this is not a new insight. However, what is new in our research is the attention given to the "freedom of learning" space which may be rather small for Dutch employees, although the general idea is that this space may actually be generous in the Netherlands, compared to other countries. It could be that in this respect the Dutch learning climate, as suggested by Jet Bussemaker, Dutch minister for Education, Culture and Science, and Lodewijk Asscher, Dutch minister for Social Affairs and Employment (2014), is an issue of concern compared to e.g. Scandinavian countries, but we do not think so. In our view, the Dutch climate seems to be not one of "learning", but one of "education" which still promotes that people should be educated (a sort of top-down prescription) for their own benefit and not so much enabled to learn by their own choice. This climate is regulated by governments, unions, educational institutions, employers' unions etc. while the people it concerns (the employees) are hardly asked what they want (WRR 2013).

\section{Discussion}

By the use of a mixed-methods research design, we took advantage of being able to combine the strengths of two distinct research phases, quantitative and qualitative. By assessing both outcomes of the sequential phases, we gained a better understanding and a more detailed and rich insight into the complicated issue of compulsion and volition, on a scale which is better and deeper than either of the methods could be by themselves. An additional attractiveness of an initially twophased project like this is the possibility to triangulate or converge the outcomes, so that the operationalised concepts can be validated in an additional third phase (see Table 3). However, several limitations of all phases should be taken into consideration, a point we will come back to later in this discussion. Despite those limitations, it emerged that there is a gap to bridge between the practice of adult education and the preached importance of lifelong learning for individuals, organisations and rapidly changing societies.

In the Netherlands, society, including the labour market, is increasingly calling for flexibility and individual responsibility in "managing" one's own life. This also applies to lifelong learning. The information provided by the Dutch employees who participated in our study indicates that they are aware of the appeal to keep learning. Like work, learning is important to them, even though (meaningful) education is not always achievable. They feel they can rarely learn what they really want, neither formally, nor non-formally. The first, formal learning, is demanding and appears to be an individual responsibility according to the information proffered by the interviewees. It is demanding because formal education hardly fits into their (work) life and into their wallet, so it is problematic to keep the work-learn-life balance. This seems to be one of the reasons why professionally qualifying education is only accessible to a small group of people. But as in most Western countries, formal learning is highly valued in the Netherlands (see our introductory section). In the 
minds and lives of the interviewed employees it also provides more job security and gives access to better jobs (enhancing employability and professional status).

As to the second, learning for work activities, i.e. both kinds of non-formal learning, WPL (on the job) and WRL (off the job), should be more accessible to a larger group of working people. Indeed, the results of our investigations seem to indicate that this is the case. But the margins of the decision space to make one's choice in WRL seem to be quite small. The constructed variable "learning opportunities" showed clear relationships with a number of other variables: workplace activities and work satisfaction, employer's necessary consent, contextual expectations to take courses and context beliefs to learning. Thus the experience with learning for work is an expression of the interdependence of employee and employer, albeit with the employer in the lead. Our constructed variables are the motivational and affective process components added to Ford's MST model (Ford 1992). These can be seen as indicators of what Illeris (2007) called the socialcultural learning environment. An environment which seems to force adult learners "into educational measures with the threat of financial and social marginalization" (Illeris 2007, p. 241, emphasis added). Nevertheless, our Dutch respondents believed that participation in decision-making and choosing the content of learning positively influenced their desire to learn and their willingness to improve their competence, a view which was confirmed by the interviewed employees.

While the distinguishing variables mentioned before were validated by the converging results of the qualitative research and findings in the literature, several limitations of all phases of the mixed-methods research should be considered. First, the use of quantitative data from a limited number of individuals within a limited number of organisations is reflected in a small sample (in phase 1). Second, due to the explorative character of our study, the reliability of a few of the intermediate conceptualisations was somewhat limited. Also the sample size in the qualitative MVS (phase 1) was a little low and did not show the variation as intended. Besides, this phase of the study was also explorative in nature. Furthermore, there is always the risk that the researcher sees what he wants to see (Flick 2007), although precautions were taken to reduce bias. Despite these limitations, the mixed-methods study did provide a deeper insight into how Dutch employees (don't) get the "work \& learn" job done.

Finally, our study confirmed that the practice of adult learning (around the workplace) is ambiguous: on the one hand there is autonomous voluntary learning to improve (work) life, on the other hand there is compulsory learning in order to adapt to the ever-changing work environment. This ambiguity is aptly illustrated by this observation (translated for the purposes of this paper) of one of the employees we interviewed:

If you want to enter somewhere nowadays, you simply have to have a diploma. So, that was also running, of course it was running through my head. Partly. In part because I really wanted it myself.

Open Access This article is distributed under the terms of the Creative Commons Attribution 4.0 International License (http://creativecommons.org/licenses/by/4.0/), which permits unrestricted use, distribution, and reproduction in any medium, provided you give appropriate credit to the original author(s) and the source, provide a link to the Creative Commons license, and indicate if changes were made. 


\section{References}

Ashton, D. A. (2004). The impact on organizational structure and practices on learning in the workplace. International Journal of Training and Development, 8(1), 43-53.

Bolt, H. F., \& Van Dellen, T. (2006). Professionele ontwikkeling in de zorg? [Professional development in welfare]. In P. W. J. Schramade (Red.), Handboek Effectief Opleiden (Vol. 42(211), pp. 18.51.01-18.5-1.12). Den Haag: Elsevier Bedrijfsinformatie B.V.

Borghans, L., Fouarge, D., De Grip, A., \& Van Thor, J. (2014). Werken en leren in Nederland [Working and learning in the Netherlands]. Maastricht: Researchcentrum voor Onderwijs en Arbeidsmarkt (ROA).

Bussemaker, J., \& Asscher, L. F. (2014). Letter to the Chairman of the Dutch Lower House, 21 October 2014. [The authors are the Minister of Education, Culture and Science and the Minister of Social Affairs and Employment, respectively.] https://www.rijksoverheid.nl/documenten/kamerstukken/ 2014/10/31/kamerbrief-leven-lang-leren. Accessed 10 November 2015.

Chisholm, L., Lunardon, K., Ostendorf, A., \& Pasqualoni, P. P. (2012). Introduction. In L. Chisholm, K. Lunardon, A. Ostendorf, \& P. P. Pasqualoni (Eds.), Decoding the meanings of learning at work in Asia and Europe (pp. 9-19). Conference series. Innsbruck: Innsbruck University press. http:// asemlllhub.org/fileadmin/www.dpu.dk/ASEM/publications/decoding_meanings_web.pdf. Accessed 4 November 2015.

Chisholm, L., Van Dellen, T., \& Lunardon, K. (2012a). Overlapping worlds: Asian and European experiences of learning and working [presentation video 12 June]. Copenhagen. http:// asemforum2012.dk/media/videos/. Accessed 4 November 2015.

Chisholm, L., Van Dellen, T., \& Lunardon, K. (2012b). Overlapping worlds: Asian and European experiences of learning and working [sheets]. Copenhagen. http://asemforum2012.dk/fileadmin/ conferences/ASEM_Conference/Keynote_Presentations/Keynote_1_-_Overlapping_worlds.pdf. Accessed 4 November 2015.

Creswell, J. W. (2007). Educational research: Planning, conducting, and evaluating quantitative and qualitative research. New Jersey: Prentice Hall.

Deci, E. L., \& Ryan, R. M. (1985). Intrinsic motivation and self-determination in human behavior. New York: Plenum.

Deci, E. L., \& Ryan, R. M. (2000). The "what" and "why" of goal pursuits: Human needs and the selfdetermination of behaviour. Psychological Inquiry, 11(4), 227-268.

Ellström, P. (2011). Informal learning at work: Conditions, processes and logics. In M. Malloch, L. Cairns, K. Evans, \& B. N. O'Connor (Eds.), The Sage handbook of workplace learning (pp. 105-120). London: Sage Publications.

Flick, U. (2007). An introduction to qualitative research (3rd ed.). London: Sage Publications.

Ford, M. (1992). Motivating humans: Goals, emotions, and personal agency beliefs. Newbury Park, CA: Sage Publications.

Friese, S. (2012). Qualitative data analysis with ATLAS.ti. London: Sage Publications.

Heckhausen, J., Wrosch, C., \& Schulz, R. (2010). A motivational theory of life-span development. Psychological Review, 117(1), 32-60.

Heidekamp, I. (2014). Passie, pecunia en lerende werknemers. Een exploratief onderzoek naar leervrijheid in de arbeidscontext [Passion, money and learning employees. An explorative research into freedom of learning in work environments]. Thesis. Groningen: University of Groningen.

Holton, E. F., \& Naquin, S. (2005). A critical analysis of HRD evaluation models from decision-making perspective. Human Resource Development Quarterly, 16(2), 257-280.

Illeris, K. (2007). How we learn: Learning and non-learning in school and beyond (2nd ed.). London: Routledge.

Ivankova, N. V., Creswell, J. W., \& Stick, S. L. (2006). Using mixed-methods sequential explanatory design: From theory to practice. Field Methods, 18(3), 3-20.

Jarvis, P. (2006). Towards a comprehensive theory of human learning. Lifelong learning and the learning society (Vol. 1). London: Routledge.

Jarvis, P. (2007). Globalisation, lifelong learning and the learning society: Sociological perspectives. London: Routledge.

Lawrence, P. R., \& Nohria, N. (2002). Driven: How human nature shapes our choices. San Francisco: Jossey-Bass. 
OECD (Organisation for Economic Co-operation and Development). (2012). Education at a Glance 2012: OECD Indicators. Paris: OECD Publishing. http://www.oecd-ilibrary.org/docserver/ download/9612031e.pdf?expires $=1446639828 \&$ id=id\&accname $=$ guest $\&$ checksum $=36233 \mathrm{D} 6 \mathrm{AC}$ 9F67210A6580E85FA775FD0. Accessed 4 November 2015.

Rocco, T. S., \& Plakhotnik, M. S. (2009). Literature reviews, conceptual frameworks, and theoretical frameworks: Terms, functions, and distinctions. Human Resource Development Review, 8(1), $120-130$.

Sloterdijk, P. (2011). Je moet je leven veranderen [You should change your life]. Amsterdam: Uitgeverij Boom.

Van Dellen, T. (2012). Motivational and affective components of workplace learning in some sectors in the Netherlands. In L. Chisholm, K. Lunardon, A. Ostendorf, \& P. Paolo Pasqualoni (Eds.), Decoding the meanings of learning at work in Asia and Europe (pp. 37-53). Innsbruck: Innsbruck University Press.

Van Dellen, T., \& Greveling, L. (2010). Workplace learning a sensitive matter? Employees' ideas on workplace learning in the Netherlands. http://asemlllhub.org/fileadmin/www.dpu.dk/ASEM/ASEMLLL-RN2_NL-Survey_finalversion.pdf. Accessed 4 November 2015.

Van Dellen, T., \& Hauwen, W. (2007). Organisatieontwikkeling in de metaal? [Organisational development in the metal sector?]. In P. W. J. Schramade (Ed.), Handboek Effectief Opleiden 44 (pp. 251-274). Den Haag: Elsevier bedrijfsinformatie B.V.

Verplaetse, J. (2008). Het morele instinct. Over de natuurlijke oorsprong van onze moraal [The moral instinct. About the natural origin of our morality] (22nd ed.). Amsterdam: Uitgeverij Nieuwezijds.

Verplaetse, J. (2012). Zonder vrije wil. Een filosofisch essay over verantwoordelijkheid [Without free will. A philosophical essay about responsibility] (2nd ed.). Amsterdam: Uitgeverij Nieuwezijds.

WRR (Wetenschappelijke Raad voor het Regeringsbeleid). (2013). Naar een lerende economie. Investeren in verdienvermogen [Towards a learning economy. Investing in the earning capability]. http://www.wrr.nl/publicaties/publicatie/article/naar-een-lerende-economie-1/. Accessed 4 November 2015 .

\section{The authors}

Theo van Dellen is an assistant professor in the Department of Educational Sciences, University of Groningen, The Netherlands. He is responsible for the topic "Transformative lifelong learning in workplaces" within the Lifelong learning programme. He strives for an integral, interdisciplinary approach of developing theory and practice which supports adult learning processes for work through subjectivity, identity construction and transformation. The outcome in terms of theory may serve to understand the affective, cognitive and social characteristics of spaces which promote learning for work. His engagement with the complex and messy realities around workplaces is supported by humanistic and positive psychology.

Ina Heidekamp is a social worker with 20 years of experience in the welfare sector. In 2015, she graduated with a Master of Pedagogical Sciences, specialising in Lifelong Learning. Being a mature student herself, she is interested in adult learning from a personal perspective, as well as professionally and scientifically. Besides adult learning theory and lifespan theory, her topics of research include motivation to learn, morals and ethics of learning (opportunities), and the importance of education in social inclusion. 